\title{
Productivity, Costs, and Selected Environmental Impacts of Remote-Controlled Mini Forestry Crawlers
}

\author{
Ferréol Berendt ${ }^{1, *}$, Mathieu Fortin ${ }^{2}$, Christian Suchomel ${ }^{1}$ and Janine Schweier ${ }^{1}$ \\ 1 Chair of forest operations, Albert-Ludwigs-University Freiburg, Werthmannstraße 6, \\ 79085 Freiburg, Germany; Christian.suchomel@foresteng.uni-freiburg.de (C.S.); \\ Janine.schweier@foresteng.uni-freiburg.de (J.S.) \\ 2 UMR SILVA, AgroParisTech/Université de Lorraine/INRA, 14 rue Girardet, 54042 Nancy, France; \\ mathieu.fortin.re@gmail.com \\ * Correspondence: ferreol.berendt@foresteng.uni-freiburg.de; Tel.: +49 7612033760
}

Received: 30 August 2018; Accepted: 19 September 2018; Published: 21 September 2018

\begin{abstract}
An effective way to reduce off-road traffic in forests is to implement greater distances between skid trails. However, this implies that trees beyond the boom reach of the harvester need to be felled motor manually before being winched to the skid trail, for example using a remote-controlled mini forestry crawler (MFC). They are only a few local studies which have evaluated the performance of such MFCs. The use of MFCs for wood extraction operations in mixed soft- and hardwood stands is presented in this study conducted in Southwestern Germany. The aim of this study was to analyze the productivity, costs, and selected environmental impacts of mini forestry crawlers during winching operations through a time study. Using statistical regression, time consumption was analyzed in order to determine significant explanatory variables. Environmental impacts were evaluated using the life cycle assessment (LCA) methodology with Umberto software. The mean net cycle time was $4.82 \mathrm{~min}$ and the net productivity rate was $7.77 \mathrm{~m}^{3}$ by productive machine hour $\left(\mathrm{PMH}_{0}\right)$. Explanatory variables which significantly affected the net cycle time were the winched volume, the number of trees per load, and winching distance. Environmental analysis showed that inputs of fossil energy were mostly due to diesel and lubricant consumption. Raw materials for machine manufacture and maintenance showed the highest impact in human toxicity potential category. The MFCs showed good environmental performances, but the harvesting system should become more productive in order to be more cost effective.
\end{abstract}

Keywords: winching; timber extraction; time consumption; LCA; energy

\section{Introduction}

The mechanization of wood harvesting operations has become increasingly popular over the last decades in order to satisfy timber demand, to enhance productivity and cost effectiveness, to reduce occupational health and safety risks, and to lessen stand damage [1-3]. This mechanization has led to higher off-road traffic levels [3], which may damage forest soils through compaction, rutting, and soil displacement. In order to maintain both stability and productivity of forest stands, disturbances of forest soils by forest operations should be minimized [4].

In the federal state of Baden-Württemberg (BW) located in Southwestern Germany, the state forestry department (Forst BW) supports the reduction of extensive off-road traffic, and therefore, a distance of at least $40 \mathrm{~m}$ between parallel skid trails is promoted for areas with sensitive soils or inclinations above 30\% [5]. In addition to reducing disturbed areas, such a distance between the skid trails is also in accordance to the German Forest Stewardship Council (FSC)-certification standard 3.0 [6]. In FSC-certified forests, no more than $10 \%$ of the area of managed forests should be used as 
skid trails, a criterion that is met by setting the distance between parallel skid trails to at least $40 \mathrm{~m}$. This may have led to increased skid trail intervals also in private-owned forests. A survey on forest operations in Southwestern BW showed that the distance between skid trails was $40 \mathrm{~m}$, in $83 \%$ of the recorded felling operations regardless of the forest ownership [7]. These conditions often lead to motor-manual felling and mechanized winching operations. Remote-controlled mini forestry crawlers (MFCs) (Figure 1) might be a suitable option to support sustainable forest operations.
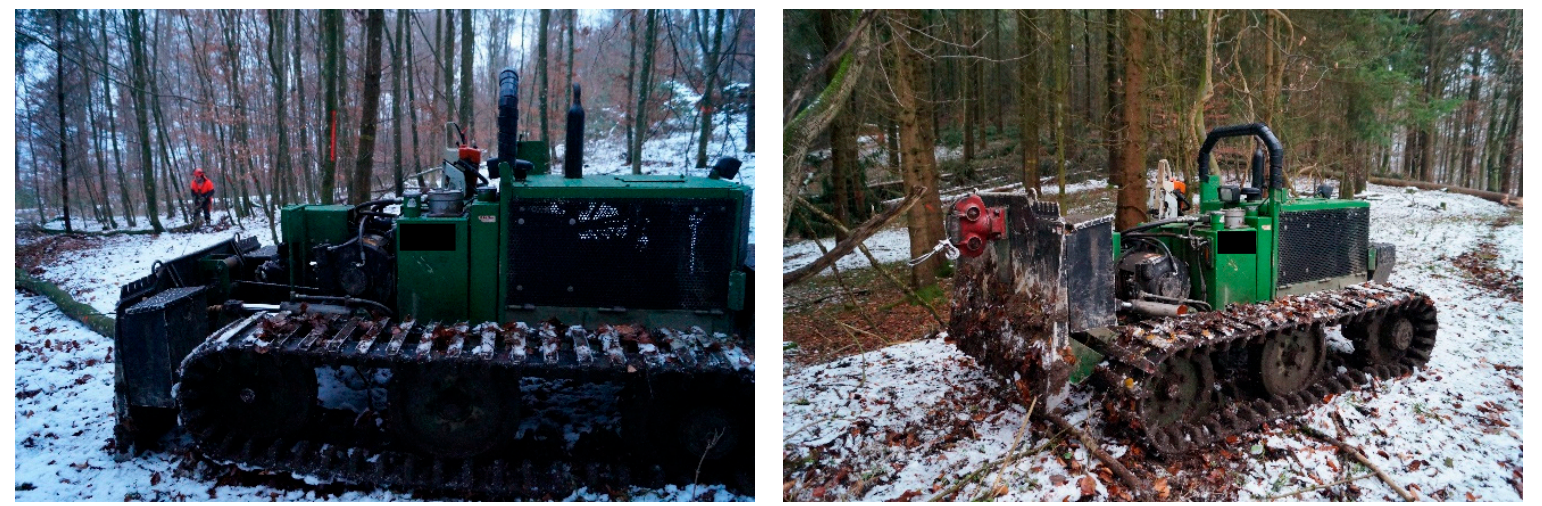

Figure 1. Remote-controlled mini forestry crawler (MFC) tested in this study.

The advantage of these MFCs is mainly the low weight between 1.4 to $2.8 \mathrm{t}$ which corresponds to a low ground pressure ranging between 0.16 and $0.30 \mathrm{~kg} / \mathrm{cm}^{2}$. Moreover, they have a gravity center located at only $60 \mathrm{~cm}$ above ground, a high climbing capacity on slopes with an inclination up to $60 \%$, are highly maneuverable and versatile in use, can easily be transported in a car trailer, and have a cost price between $€ 48,000$ and 98,000 for an engine ranging from 35 to $65 \mathrm{HP}$ [8-16]. Currently, there are at least eight different models available on the market from different brands [11] and foresters as well as operators are seeming to gain interest in this technology.

Over the last years, performance indicators focused on energetic inputs and greenhouse gas (GHG) emissions of forest operations have become a popular evaluation criterion to ensure and enhance the environmental performance of operations. Studies have shown that over $85 \%$ of the energy inputs were caused by fuel consumption of machines [17]. Therefore, it is crucial to analyze not only the machine productivity, but also related potential environmental impacts. To the best of our found knowledge, no peer-reviewed publication in English language has yet addressed the productivity, costs, and associated environmental impacts of MFCs.

The change of forest types towards higher proportions of broadleaved trees may increase wood extraction time. Broadleaved species usually exhibit larger branches and more complex crown structures. Consequently, it could be expected that the winching of broadleaved trees would take more time than that of a conifer trees, all other things being considered. Moreover, slope inclination, the distance to the skid trail, and the volume being winched can all be considered as constraints. Consequently, it was hypothesized that they would all negatively affect the time consumption of a winching cycle. More precisely, the objectives of this study were:

- $\quad$ to carry out a time study in order to gain knowledge on the different work elements and their time consumption and thus to calculate productivity and costs,

- to estimate by regression the relationships between operational parameters and time consumption, and

- $\quad$ to evaluate the machine performance in terms of common environmental impacts: global warming potential (GWP), acidification potential (AP), eutrophication potential (EP) and human toxicity potential (HTP). 


\section{Material and Methods}

\subsection{Study Sites}

This research focused on wood harvesting that included motor-manual felling and winching operations as offered by commercial operators. The study site was located in the federal state of BW (Southwest Germany), more specifically in the region of the lake Constance $\left(47^{\circ} 52^{\prime} 06.9^{\prime \prime} \mathrm{N} / 9^{\circ} 01^{\prime} 01.4^{\prime \prime} \mathrm{E}\right)$, which is between 500 and $600 \mathrm{~m}$ above sea level. European beech (Fagus sylvatica L.) was the dominant tree species in the mixed stands with proportions of $53 \%$. In addition to beech, the forests contain mainly Norway spruce (Picea abies H. Karst) with a proportion of $25 \%$, Silver fir (Abies alba Mill.) (3\%), Douglas fir (Pseudotsuga menziesii Franco) (6\%), Scots pine (Pinus sylvestris L.) (4\%), European larch (Larix decidua Mill.) (3\%), and different broadleaved species (6\%), mostly oaks (Quercus robur L. and Quercus petraea Liebl.), as individuals or smaller groups. The study was carried out between December 2017 and January 2018.

The height and diameter at breast height (DBH) of 34 beech and 18 coniferous trees (16 spruce and 2 silver fir trees) were measured in order to fit a local height-diameter equation. For beech trees, the DBH ranged from 8 to $43 \mathrm{~cm}$, with a mean of $21.2 \mathrm{~cm}$ and a standard deviation of $7.5 \mathrm{~cm}$. For conifers, mean DBH was $24.3 \mathrm{~cm}$ with a standard deviation of $4.0 \mathrm{~cm}$. The resulting equation was then used to predict the height of all harvested trees. All other broadleaved trees that were not beech $(n=3)$ were estimated using the equation of beech. Tree volume was estimated using the volume equation provided in Deleuze et al. [18]:

$$
\text { VTot }=\mathrm{f} \frac{\mathrm{h} \times \mathrm{c}^{2}}{4 \pi\left(1-\frac{1.3}{\mathrm{~h}}\right)^{2}}
$$

where VTot is total aboveground tree volume, $\mathrm{f}$ is the form factor depending on the tree species, $\mathrm{h}$ is the tree height, and $c$ is the circumference at breast height. A form factor of 0.515 was used for beech and 0.496 for conifers [18].

\subsection{System Description, Work Organization, and Data Collection}

A two-person team felled the trees motor-manually then winched the whole trees to the skid trails using the MFC. Motor-manual felling was done using a chainsaw (i) for the trees beyond the boom reach of the harvester, (ii) for the trees with DBH that exceeded the maximum felling diameter of the harvester head, and (iii) for the broadleaved trees with widespread crown and thick branches which could cause problems during the harvester processing. During winching, the logs were moved from the felling site to the skid trails, where the harvester could process them except for trees with widespread crown and thick branches, which were processed motor manually. Each task was entrusted to one experienced worker: one felled the trees using the chainsaw, while the second operated the MFC. Although the overall production system included both workers as they worked as a pair, the time consumption was recorded for the MFC operator only. After the trees were winched, a harvester felled and processed the trees within the boom reach and processed the bunched trees. Finally, the extraction was done by a forwarder. The wood harvesting system according to the German Center for Forest Work and Technology (KWF) [19] is shown in Figure 2. Besides winching, the MFC was also used to assist with pulling hung-up trees during the felling.

The system boundaries were set to those of the winching operation and the functional unit (FU) used in the analyses was the cubic meter over bark $\left(\mathrm{m}^{3}\right)$ of fresh wood, as it is the most common FU in forestry [20]. A work cycle consisted of extracting one or more trees in a single winching from the felling site to the skid trails. The following work elements were observed in each work cycle and considered as mandatory: pulling out the cable (pulling), chocking, winching, and unchocking. All other work tasks did not necessarily occur in each cycle and were therefore considered as optional tasks: setting up the machine, travelling and positioning the machine on the skid trail (positioning), chocking again 
the cable because it was not properly fixed (rechocking), waiting for the felling (feller), consulting the feller (consultation), personal delays, machine delays, cleaning the skid trails, and operating the chainsaw (chainsaw). In some cases, the MFC operator used a second chainsaw, mostly to support the feller. Nevertheless, net productive working time was included as all mandatory tasks as well positioning, rechocking, feller, consultation, cleaning, and chainsaw. The two workers as a system were considered, and therefore the following work elements were considered as productive work time: feller, consultation, chainsaw. Cleaning the skid trail was part of the work order, and as a consequence it was also accounted as productive work time.

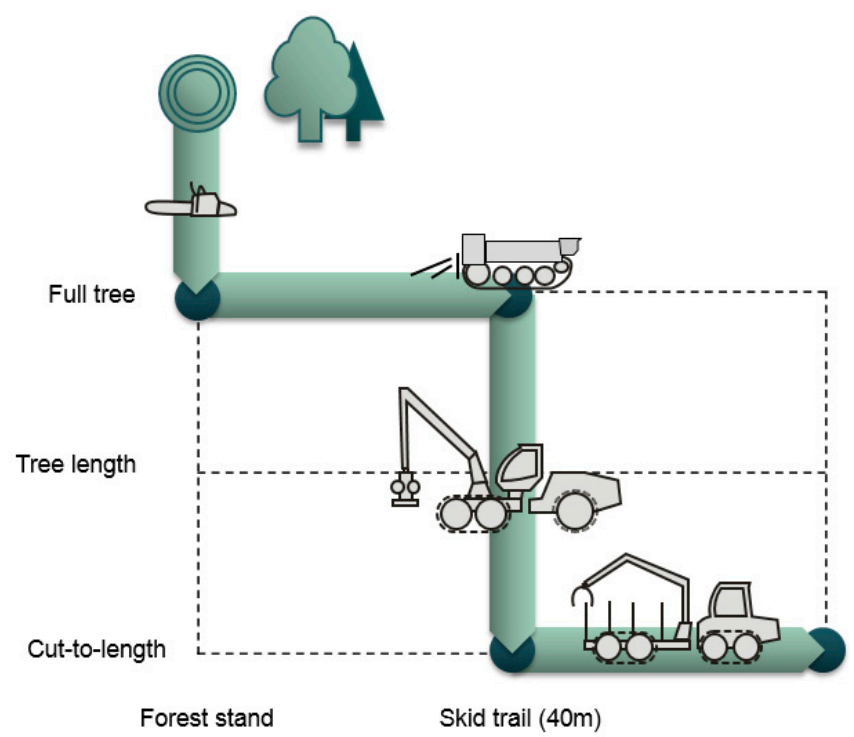

Figure 2. Representation of the wood harvesting and extraction operation.

All of the work elements were observed during the time study. For the analysis, the optional tasks "feller", "consultation", "cleaning" and "chainsaw" were grouped under the label "other work elements". Likewise, personal and machine delays were grouped under the label "delays".

Time consumptions were observed for two teams working with the same machine in two felling blocks. The felling blocks were within the same forest district.

Along with the time consumption in 1/100 min, cable pulling/winching distance, number of trees, tree DBH and slope inclination were recorded. Pulling/winching distance was measured using a laser measuring device (DISTO pro, Leica Geosystems AG, Heerbrugg, Switzerland), DBH was measured using a caliper and slope inclination was estimated using a clinometer (PM-5, Suunto, Vantaa, Finland). Slope inclination was categorized into flat ground or slight slopes $(\leq 10 \%)$ [21], medium slopes (10-45\%) and steep slopes ( $\geq 45 \%)$ [5]. Pulling direction was downwards and winching was done uphill.

The MFC was constructed by a German manufacturer (F. Müller Fahrzeugbau GmbH \& Co KG, Eslohe-Bremke), being powered by a $25 \mathrm{~kW}$ diesel engine and weighing $1900 \mathrm{~kg}$ for $1750 \mathrm{~mm}$ in width and $2400 \mathrm{~mm}$ in length. The MFC was driven on the skid trails only and never entered in the stands. It was equipped with a winch having a nominal traction force of $50 \mathrm{kN}$ and a $10 \mathrm{~mm}$-diameter and $70 \mathrm{~m}$-long rope. Moreover, the machine was equipped with a front blade and a second winch at the machine tail as integrated tethering winch. Information about machine characteristics is available from the manufacturer [15].

\subsection{Economic Analysis}

Machine costs were estimated using the method developed by the European Cooperation in Science and Technology Action FP0902 [22]. The Microsoft Excel-based spreadsheet model was developed by Ackerman et al. [22] to establish a common framework for machine cost calculation 
in the forest biomass procurement chain. Using this framework, the costs were calculated based on fixed costs, variable costs, and operator costs [22]. Input data (Table 1) were obtained from personal communication with machine user for service life, annual use, insurance costs, repair and maintenance costs [23] and from literature [11,22,24,25]. A salvage value of $10 \%$ was recommended by Ackermann et al. [22] as a rule of thumb because there is a lack of studies dealing with salvage values of machines [22]. Labor costs and social charges (non-wage labor costs) are closely related and they were obtained from KWF [24] for German conditions (2016).

Table 1. Costing: assumptions, cost items and total.

\begin{tabular}{ccc}
\hline Characteristic & Unit & MFC \\
\hline Initial investment a & $€$ & 63,000 \\
Salvage value (as \% of purchase price) b & $\%$ & 10 \\
Service life c & years & 8 \\
Annual use c & h/year & 1000 \\
Fuel consumption e & $\mathrm{L} /$ PMH15 & 2 \\
Interest & $\%$ & 4 \\
Insurance c & $€ /$ year & 700 \\
Diesel d & $€ / \mathrm{L}$ & 1.60 \\
Lube (as \% of fuel cost) b & $\%$ & 10 \\
Repair \& Maintenance c & $€ / \mathrm{h}$ & 2 \\
Labor d & $€ / \mathrm{h}$ & 1350 \\
Social charges (\%) d & $\%$ & 125 \\
\hline a [11], ${ }^{\mathrm{b}}$ [22], ${ }^{\mathrm{c}}$ personal communication from machine user, ${ }^{\mathrm{d}}$ [24], ${ }^{\mathrm{e}}[25]$.
\end{tabular}

Total system costs including harvester and forwarder were calculated with the HeProMo productivity calculation tool from the Swiss Federal Institute for Forest, Snow, and Landscape Research [26]. Harvester and forwarder costs were assumed to be $155 € / \mathrm{h}$ and $95 € / \mathrm{h}$, respectively. Input parameters for the total system cost analysis were set to $\mathrm{DBH} 30 \mathrm{~cm}, 69 \%$ broadleaved trees, normal stem form, up to $50 \%$ winched timber (to the skid trail), two assortments with a length of $4 \mathrm{~m}, 250 \mathrm{~m}$ forest roads, and $400 \mathrm{~m}$ skid trails. For the sake of comparison, a fully mechanized forest operation (i.e., harvester and forwarder in stands with skid trail distance of $20 \mathrm{~m}$ ) were simulated without winching, but with total skid trail distance of $800 \mathrm{~m}$ were assumed.

\subsection{Environmental Analysis}

The modeling software Umberto (v. 5.6) [27] was used to assess the cumulative energy demand (CED) of fossil energy and selected environmental impacts associated to the manufacture and the use of the MFC. Calculations were conducted in accordance with the methods of life cycle assessment (LCA), which are described in detail in the ISO 14000 [28] series standards [29]. Emission data were obtained from the Ecoinvent database [30] which is implemented into Umberto software. In this study, the environmental impact categories GWP, AP, EP, and HTP were assessed. The GWP is impacted mainly by the emission of greenhouse gases, and was calculated for a time frame of 100 years. The AP indexes nutrient losses in ecosystems, and thus, it stands for the contribution to decrease of the $\mathrm{pH}$ value in the environment. Eutrophication originates mainly from nitrogen and phosphorus in sewage outlets and fertilizers. The HTP is an index that reflects the potential harm of a unit of chemical released into the environment. The GWP, $\mathrm{AP}, \mathrm{EP}$ and $\mathrm{HTP}$ are reported in $\mathrm{CO}_{2}$-eq., $\mathrm{SO}_{2}$-eq., $\mathrm{PO}_{4}{ }^{3-}$-eq. and 11.4-dichlorobenzene (1.4-DCB)-eq., respectively.

The life cycle inventory was organized in three steps: (i) the raw materials of one MFC, (ii) the energy inputs required for machine manufacture and assembling, and (iii) the machine use (diesel and lubricants consumption).

Data regarding the mass of the different raw materials were obtained in a personal communication from a manufacturer of another type of MFC (Table 2). Most data were obtained in kg excepting the electric cables and hydraulic pipes which were given in $\mathrm{m}$. For electric cables a weight of 0.22 
$\mathrm{kg} / \mathrm{m}$ and a composition of 35\% copper to 65\% polyvinylchloride (PVC) were assumed. Hydraulic pipes were assumed to have $0.64 \mathrm{~kg} / \mathrm{m}$ in weight and material composition of $90 \%$ rubber to $10 \%$ steel. The motor was assumed to be manufactured out of cast iron. For the battery a lead-acid battery composed of $75 \%$ secondary lead and $25 \%$ polypropylene (PP) was assumed [31]. Crawler tracks are made from rubber and are steel reinforced: the assumption was $75 \%$ rubber and $25 \%$ steel.

Table 2. Input data regarding the machine production of one MFC.

\begin{tabular}{ccc}
\hline Material & Mass (in \%) & Mass (in kg) \\
\hline Steel & 52.0 & 989 \\
Cast iron & 22.3 & 424 \\
Crawler tracks & 7.4 & 141 \\
Plastics/PVC & 3.1 & 59 \\
Electronic cables & 0.7 & 36 \\
Hydraulic pipe & 1.9 & 14 \\
Motor & 11.2 & 212 \\
Battery & 1.3 & 25 \\
\hline
\end{tabular}

During manufacturing and assembling stages both electric and heat energy are required. As no data were available for MFC the data from Athanassiadis et al. [31], who reported values for the construction of a forwarder, were used. Energy sources required for machine manufacture were assumed to be electricity, oil, coal, natural gas, liquefied petroleum gas (LPG), district heat, and diesel; whereas for machine assembling, electricity, district heat, and diesel were required (Table 3) [31]. A repair factor of $30 \%$ was assumed along the entire lifetime [32], as well as the transportation of the machine from the manufacturing to the operator's place $(460 \mathrm{~km})$. Inputs were estimated for the number of hours of use during the present study in relation to the total hours scheduled for the life cycle of the machine. Hydraulic oil consumption was assumed to be $2.8 \%$ and engine oil $0.75 \%$ of diesel consumption, according to data that are typical for small forwarders in Ireland [29].

Table 3. Input data regarding energy source for machine manufacture and machine assembling in MJ per $\mathrm{kg}$ of machine, adapted from Athanassiadis et al. [31].

\begin{tabular}{ccc}
\hline Energy Source & $\begin{array}{c}\text { Manufacture } \\
\text { (in MJ/kgachine) }\end{array}$ & $\begin{array}{c}\text { Assembling } \\
\text { (in MJ/kg } \mathbf{m a c h i n e} \text { ) }\end{array}$ \\
\hline Electricity & 6.0 & 1.9 \\
Oil & 0.7 & - \\
Coal & 0.4 & - \\
Natural gas & 0.7 & - \\
Liquefied petroleum gas & 0.4 & - \\
District heat & 1.4 & 2.2 \\
Diesel & 0.7 & 0.7 \\
\hline
\end{tabular}

\subsection{Statistics}

Regression analysis was used to estimate the effect of load volume, pulling/winching distance, number of trees, terrain slope, and tree species on the time required to perform a complete work cycle. During preliminary trials, violations of the assumption of normality were observed and consequently, time data were mathematically log-transformed [33], i.e., $y=\ln (t+1)$ where $t$ is the time. The back transformation of log-transformed prediction to the original scale is biased [34], and therefore, the correction factor based on the residual variance and the degrees of freedom provided in Végiard and Ung [35] were used. During the regression analysis, the effect of the team was also considered as a random effect using a mixed-model approach. The reader is referred to Pinheiro and Bates [36] for further details about this approach. The relevance of the random effect was tested through a likelihood ratio test as suggested in Pinheiro and Bates [36] (p. 83). 
Moreover, as optional tasks were not done in every cycle, the effect of potential explanatory variables on whether the work element will be conducted within the cycle was tested. This was done using a generalized linear model (glm function in R) for each optional task.

\section{Results}

\subsection{Time Consumption and Productivity}

A total of $150.3 \mathrm{~m}^{3}$ or 320 pieces were winched in 241 cycles (Table 4). The average number of pieces per load was 1.3 and mean load volume was $1.6 \mathrm{~m}^{3}$. A total of 1507.37 minutes (min) were recorded. After removing delays caused by the study design and breaks 1377 min were analyzed, which corresponded to the scheduled machine hours (SMHs). Time corresponding to the productive machine hour $\left(\mathrm{PMH}_{0}\right)$ was $1161 \mathrm{~min}$, resulting in a machine utilization rate of $84 \%$. The overall gross productivity, based on SMHs, led to a productivity rate of $6.55 \mathrm{~m}^{3} / \mathrm{h}$. When considering the productive work time $\left(\mathrm{PMH}_{0}\right)$, the overall net productivity was $7.77 \mathrm{~m}^{3} / \mathrm{h}$.

When looking at the net cycle time, the working elements with the highest time consumption were the winching with $1.31 \mathrm{~min}$ per cycle $(27.2 \%)$, followed by the waiting for the feller $(14.6 \%)$, the pulling $(13.0 \%)$ and the positioning $(11.8 \%)$. On average, the total chocking time took $0.70 \mathrm{~min}$ per cycle $(14.6 \%)$, standing for $0.35 \mathrm{~min}$ for the first chocking, and 0.35 for the rechocking work elements (Table 5).

A total time of $22.1 \%$ was found to correspond to the interaction between the two workers which occurred when: (i) an MFC operator had to wait for the feller, (ii) communication and consultation between them were conducted, and (iii) an MFC operator used a second chainsaw (located in the MFC), and thus took over the work of the chainsaw operator. In the structure of other tasks, which accounted for $26 \%$ of the net cycle time, $55.7 \%$ of the time was spent for waiting for the feller, $26.2 \%$ for consulting with the feller, $11.8 \%$ for handling a chainsaw, and $6.3 \%$ for cleaning the skid trails from branches.

Table 4. Characteristics of the winching operations.

\begin{tabular}{cc}
\hline Characteristic & Value \\
\hline Total SMH $(\mathrm{h})$ & 22.95 \\
Total $\mathrm{PMH}_{0}(\mathrm{~h})$ & 19.35 \\
Work cycles & 241 \\
Mean pulling distance $(\mathrm{m} \pm \mathrm{SD})$ & $17.5 \pm 10.1$ \\
Share of beech $(\%)$ & 69.1 \\
Share of conifers $(\%)$ & 30.9 \\
Total volume $\left(\mathrm{m}^{3}\right)$ & 150.3 \\
Productivity $\left(\mathrm{m}^{3} / \mathrm{SMH}\right)$ & 6.55 \\
Productivity $\left(\mathrm{m}^{3} / \mathrm{PMH}\right)$ & 7.77 \\
Mean volume $/ \mathrm{cycle}_{0}( \pm \mathrm{SD})$ & $0.62 \pm 0.54$ \\
Mean trees $/$ cycle $( \pm \mathrm{SD})$ & $1.33 \pm 0.68$ \\
\hline
\end{tabular}

Table 5. Mean ( \pm standard deviation) net time consumption of the work elements.

\begin{tabular}{ccc}
\hline Work Element & $\begin{array}{c}\text { Mean } \pm \text { SD } \\
\text { (in 1/100 min) }\end{array}$ & $\begin{array}{c}\% \\
\text { (of Cycle Time) }\end{array}$ \\
\hline Mandatory tasks & & \\
\hline Pulling & $0.62 \pm 0.46$ & 13.0 \\
Chocking & $0.35 \pm 0.45$ & 7.3 \\
Winching & $1.31 \pm 1.21$ & 27.2 \\
Unchocking & $0.35 \pm 0.33$ & 7.2 \\
\hline Optional tasks & & \\
\hline Positioning & $0.57 \pm 0.89$ & 11.8 \\
Rechocking & $0.35 \pm 0.83$ & 7.4 \\
Other tasks & $1.26 \pm 1.77$ & 26.2 \\
\hline
\end{tabular}


The statistical analysis showed that the likelihood ratio test was non-significant $(p=0.4943)$, indicating that either the team random effect was nonexistent or the sample size was too small to estimate the variance of this random effect. Consequently, the data from both teams were analyzed without distinction and the linear model was selected (Equation (2)) to predict winching cycle time. In the final model, the statistically significant explanatory variables were the winched volume (V), the number of trees in the load $\left(\mathrm{N}^{\circ}\right)$, and winching distance (Dist). Tree species and slope inclination were not found to be significant with $p$-values of 0.057 and 0.273 , respectively. The regression which showed a $R^{2}=0.39$ is presented in Equation (2).

$$
\mathrm{y}=\mathrm{e}^{0.921+0.218 \times \mathrm{V}+0.018 \times \text { Dist }+0.185 \times \mathrm{N}^{\circ}+\frac{0.399^{2}}{2}}+1
$$

where $\mathrm{y}$ is time consumption in min, $\mathrm{V}$ is winched volume, Dist is pulling/winching distance and $\mathrm{N}^{\circ}$ is number of trees winched. Note that the factor $0.399^{2} / 2$ is actually the correction factor for the back transformation.

When including delays up to $15 \mathrm{~min}$ in the productive work time, which is a common practice in most central European countries to describe system performance [37], $\mathrm{PMH}_{15}$ had a cycle time of $5.35 \mathrm{~min}$ and an output of $6.99 \mathrm{~m}^{3} / \mathrm{PMH}_{15}$. Looking more specifically into the delays, $67.7 \%$ of the interruptions were caused by personal delays, and $32.3 \%$ by machine delays. Mean delay time per cycle was $0.34 \pm 1.33$ which represents $6.4 \%$ of total $\mathrm{PMH}_{15}$ cycle time.

For the optional tasks, significant effects were only found in the work tasks of rechocking and delays. For rechocking, the number of trees per load as well as the winching distance significantly $(p<0.005)$ increased the occurrence of rechocking. Winching distance significantly $(p<0.005)$ increased the occurrence of a delay during the cycle.

\subsection{Costs}

According to the COST Action FP0902 model for calculation of forest operation costs [22], net costs (excluding profit margin) for the two-person-team for felling and winching to the skid trail was estimated at $99.43 € / \mathrm{PMH}_{0}$ for an expected working life span of $8000 \mathrm{~h}$. That resulted in $12.80 € / \mathrm{m}^{3}$ for $\mathrm{PMH}_{0}\left(7.77 \mathrm{~m}^{3} / \mathrm{h}\right)$, split into fixed costs $\left(1.12 € / \mathrm{m}^{3}\right)$, variable costs $\left(2.48 € / \mathrm{m}^{3}\right)$, and operators costs $\left(9.20 € / \mathrm{m}^{3}\right)$.

According to HeProMo calculations, the total system costs per $\mathrm{PMH}_{15}$ was $30.31 € / \mathrm{m}^{3}$ divided in costs for winching $\left(13.93 € / \mathrm{m}^{3}\right)$, harvesting and processing $\left(8.58 € / \mathrm{m}^{3}\right)$, and forwarding $\left(7.80 € / \mathrm{m}^{3}\right)$. Compared to a conventional system with $20 \mathrm{~m}$-distances between skid trails, the system was $7.70 € / \mathrm{m}^{3}$ more expensive. In the conventional system (harvester-forwarder) costs were $10.90 € / \mathrm{m}^{3}$ for the harvester and $11.71 € / \mathrm{m}^{3}$ for the forwarder.

\subsection{Energy Consumption and Environmental Impacts}

The consumption of fossil energy was estimated at $15.8 \mathrm{MJ} / \mathrm{m}^{3}$. The CED in the life cycle of an MFC are mainly due to the consumption of diesel (74.5\%) and lubricants $(3.9 \%)$ during the machine use. The production of the machine's raw materials represented $6.4 \%$ and the energy for machine manufacture and maintenance $10.4 \%$ of CED.

Potential environmental impacts in respected categories were evaluated at $0.321 \mathrm{~kg} \mathrm{CO}$-eq. $/ \mathrm{m}^{3}$ in $\mathrm{GWP}_{100}, 1.64 \times 10^{-3} \mathrm{~kg} \mathrm{SO}$-eq. $/ \mathrm{m}^{3}$ in $\mathrm{AP}, 6.31 \times 10^{-4} \mathrm{~kg} \mathrm{PO}$-eq. $/ \mathrm{m}^{3}$ in $\mathrm{EP}$ and $0.201 \mathrm{~kg}$ 1.4-DCB-eq. $/ \mathrm{m}^{3}$ in the HTP. Diesel consumption during machine use was the most impacting in both categories GWP (with 40.7\%) and AP (with 61.8\%), whereas in the HTP steel was the most impacting (64.4\%) and in EP electricity (41.7\%) (Figure 3). 


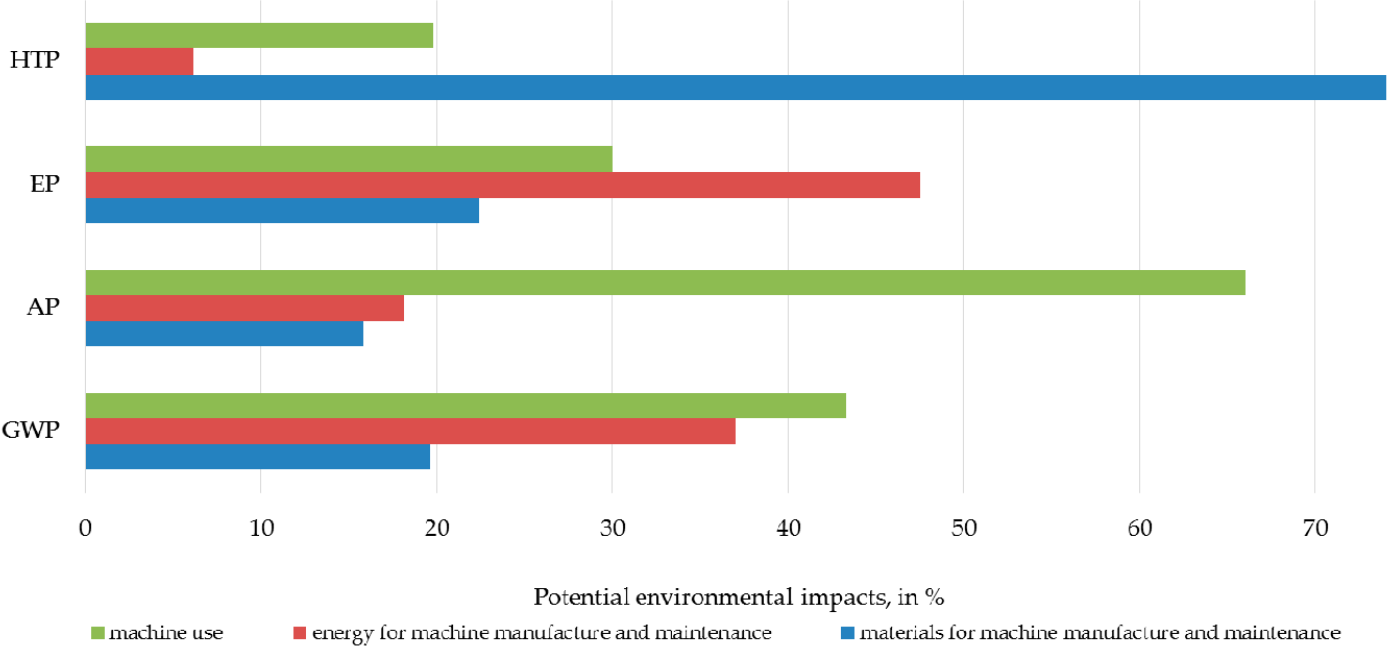

Figure 3. Potential environmental impacts in the categories human toxicity (HTP), eutrophication (EP), acidification (AP) and global warming (GWP), and divided in (i) maintenance and machine use (in green), (ii) energy consumption for machine manufacture (in red), and (iii) materials for machine manufacture and maintenance (in blue), in \%.

When looking at GWP (Figure 4), the most impacting factor was the diesel consumption for machine use $(40.7 \%)$, followed by electricity $(20.6 \%)$ and district heat $(11.5 \%)$ input during machine manufacture, assembling, and maintenance.

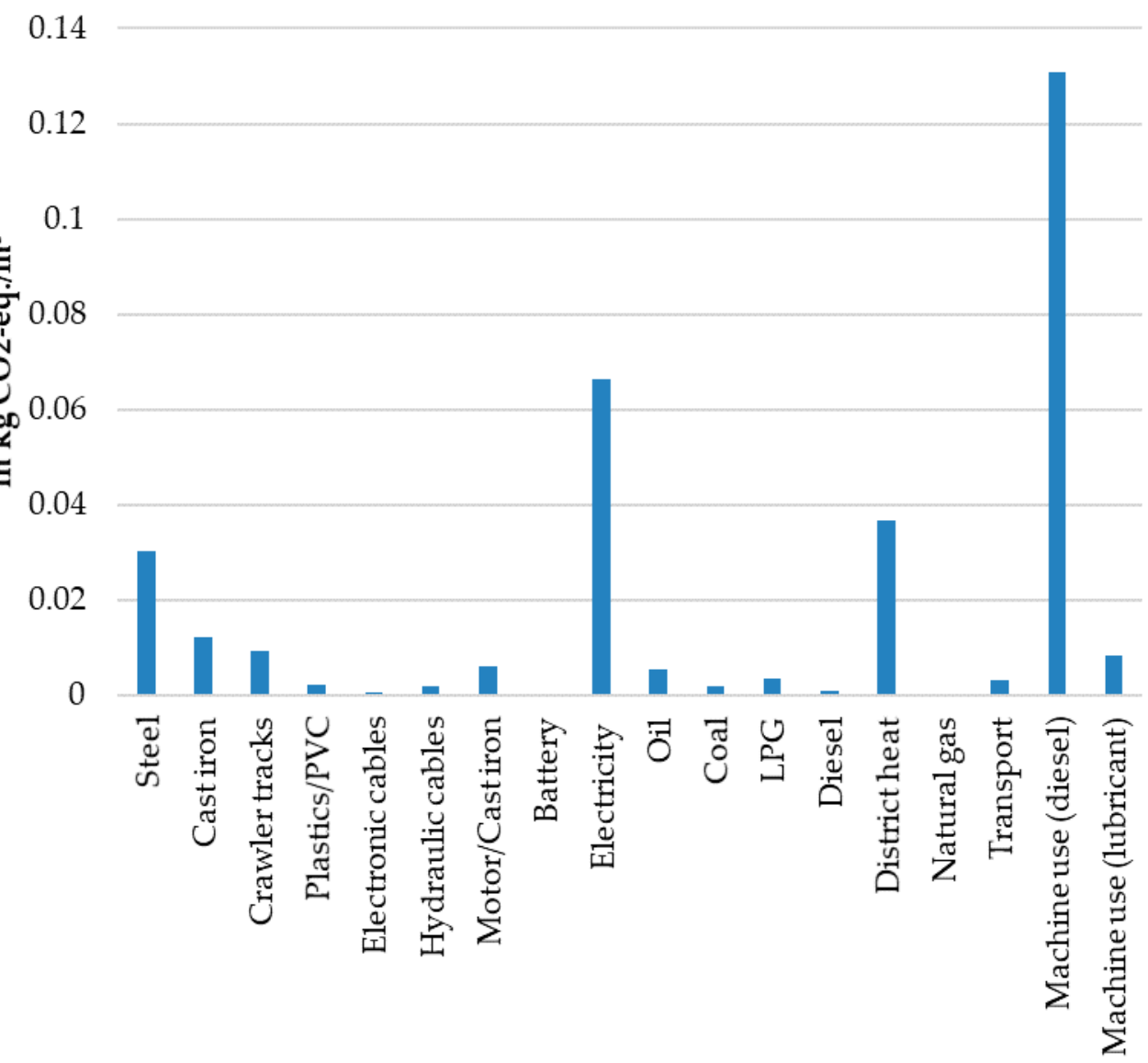

Figure 4. Global warming potential of the manufacture and use of an $\mathrm{MFC}$ in $\mathrm{kgCO}_{2}$-eq for $1 \mathrm{~m}^{3}$ of winched timber. 
The combined impact of steel, electricity, and diesel consumption during machine use accounted for $72.0 \%, 75.8 \%, 81.4 \%$, and $85.6 \%$ in GWP, AP, EP, and $\mathrm{HTP}$, respectively.

\section{Discussion}

\subsection{Time Consumption and Productivity}

In this study, two different teams in two felling blocks were monitored in order to estimate the productivity, the energy input, and selected environmental impacts of winching operations with an MFC. No significant random effect on the team in terms of time consumption were found in this study. Either this random effect was non-existent or the sample size was too small to estimate its variance. However, this could also be due to the fact that both teams were skilled.

The explanatory variables VTot, number of trees and winching distance were found to have a significant effect on the duration of the cycle time. These results were in accordance with those of previous studies $[38,39]$. It means that productivity is negatively impacted by the winching distance. On the contrary, increasing the volume (either due to size of the tree or by increasing the number of stems) resulted in growth of productivity. Nevertheless, load is limited by the weight of MFC $(1900 \mathrm{~kg})$ and the nominal traction force of the winch $(50 \mathrm{kN})$. The effect on productivity was completely in line with the so-called "piece-volume-law", which states that increasing piece size typically results in increased production and which is described by different authors [40,41].

Tree species had no significant effect on winching time consumption with MFC. This finding is in accordance with those from simulations in the USA where skidding time was not affected by the species mix [38] even if the management was different from that of this study. Nevertheless, hardwood trees often exhibit complex and variable crown architectures [42] and wood density of beech is higher than wood density of spruce [43]. Due to tree form and wood density, an effect of tree species on time and productivity was expected. According to a German survey, forest machine operators think hardwoods negatively impact productivity [7]. However, it must be stressed that the $p$-value was 0.057 , and thus, if increasing sample size it is probable that tree species would have an effect. Especially when adding data from older stands with greater DBHs and volume per tree, a tree species effect may occur as wider crowns develop, resulting in higher masses to be moved for broadleaved trees. Indeed, it could be difficult to separate the effect of tree species because of the small volumes winched. Further investigations and, in particular for final felling operations, would be helpful to complement the productivity model, in order to reach higher variability of the volumes.

The second explanatory variable which was not significant in the survey was the slope inclination. It is likely due to winching direction and slope gradient affect time consumption in the case of manual cable pulling [44]. Nevertheless, the analysis showed significant explanatory variables and interesting findings for optional tasks. As the times spent for waiting the feller or for consulting with the feller were roughly $20 \%$ of the total cycle time, increasing the productivity seems to be feasible with a better time management. However, pulling out a steel cable is a highly physical work [45], and the waiting time gives the opportunity to rest for the MFC operator. Productivity increment could also be achieved by finding ways to exclude the occurrence of rechocking operations. The number of trees loaded and the winching distance increased the occurrence of rechocking. To this end, a better positioning of the MFC could reduce the number of obstacles (stumps, trees, rocks) along the winching path, which were the reasons for rechocking. Other observed reason of rechocking was that the hook was not properly fixed and slided off the stems, which mainly occurred when the load contained more than one tree. An option to overcome this could be to equip the cable with two chockers.

The productivity results of the present study were compared to data reported by previous observations. The only data on productivity of MFC were described by ForstBW during the KWF-Tagung in Roding, Germany (2016). Mean productivity was $14.5 \mathrm{~m}^{3} / \mathrm{h}$ with values ranging from 7.0 to $21.4 \mathrm{~m}^{3} / \mathrm{h}$ [9], and it was probably related to a different stand structure and silvicultural treatment as the mean DBH was $30 \mathrm{~cm}$ and the mean volume per tree was of $1.0 \mathrm{~m}^{3}$. 
Another German study compared bunching productivity of horses and tractors. Among its findings, the productivity was estimated at $5.02 \mathrm{~m}^{3} / \mathrm{h}$ compared to $6.24 \mathrm{~m}^{3} / \mathrm{h}$ for tractors in conditions of a payload of $0.34 \mathrm{~m}^{3}$ and a distance up to $16 \mathrm{~m} \mathrm{[46],} \mathrm{being} \mathrm{lower} \mathrm{than} \mathrm{the} \mathrm{reported} \mathrm{herein.}$ Zečić et al. [47] reported a productivity rate of $21.59 \mathrm{~m}^{3} /$ day for skidding uphill with a tractor with mean loads of $0.76 \mathrm{~m}^{3}$ over a distance of $25 \mathrm{~m}$ in thinning beech stands. In addition to winching, the authors also recorded driving the loaded tractor (C Holder $870 \mathrm{~F}$ ) to the landing site and the driving of the unloaded tractor along the skid trails which could explain the differences. Moreover, unsettled weather conditions with rain and snow hampered the tractor. Other productivity studies [39,48-52] reporting on wood extraction operations are not comparable with this study as (i) longer skidding and extraction distances were reported, (ii) the operation included loaded travel on skid trails to landing site, and (iii) landing operations were mostly performed. Another study separated the winching operation from the extraction so that productivities of winching were reported. For example, for a broadleaved mixed stand in Romania, a net production rate of $25.31 \mathrm{~m}^{3} / \mathrm{h}$ was reported for winching $9 \mathrm{~m} \mathrm{[39].}$ This high value is hardly comparable with a study like this on MFCs for different reasons: (i) less or no waiting time was observed because after the winching operation the skidder immediately extracted the timber to the landing site; (ii) there were higher load volumes, and (iii) winching was completed on shorter distances.

\subsection{Costs}

Operator costs $\left(9.20 € / \mathrm{m}^{3}\right)$ largely exceed fixed $\left(1.12 € / \mathrm{m}^{3}\right)$ and variable $\left(2.48 € / \mathrm{m}^{3}\right)$ costs. These high operator costs are due to high social charges in Germany and because both forestry workers were considered (the feller and the MFC operator). The study from ForstBW (2016) about MFC estimated mean net costs for winching with a two-person team to be $6.29 € / \mathrm{m}^{3}$ with values ranging from 4.52 to $13.83 € / \mathrm{m}^{3}$ [9], compared to $12.80 € / \mathrm{m}^{3}$ in this study. The difference in costs was probably related to a different stand structure and management (e.g., final felling).

Total system costs were evaluated at $30.31 € / \mathrm{m}^{3}$ compared to $22.26 € / \mathrm{m}^{3}$ for a conventional harvester-forwarder system. To the best of author's knowledge, system costs of $30.31 € / \mathrm{m}^{3}$ are still cost-covering, and thus economically feasible. But, as a consequence, profit margins will be lowered. The forest owner needs to tradeoff between lower off-road traffic area and a higher profit margins, unless production costs decrease or monetary compensations are paid out. The application of a multi-criteria analysis, which has been richly taken up as a decision-support tool in forest management planning and practice, might help to compare alternative management operations on a cumulative preference scale [53].

The differences between the costs of timber harvesting system with MFC and the conventional one can be mainly explained by increased man power for the system with MFC. Nevertheless, harvester and forwarder costs are higher in the conventional system: 8.58 to $10.90 € / \mathrm{m}^{3}$ and 7.80 to $11.71 € / \mathrm{m}^{3}$, respectively.

Winching and bunching felled trees next to the skid trail may increase the productivity of harvesters and forwarders. A higher productivity of forwarders was also observed by Mederski et al. [54,55] when bigger piles of wood were created next to the skid trails. Further research on winching should compare following whole timber harvesting systems: the one-harvester-pass and the two-harvester-pass systems as described by Mederski et al. [54,55] with lateral winching.

\subsection{Environmental Impacts}

Most of the forest-related LCA studies are based on direct process energy inputs and neglect the upstream processes related for instance to machine manufacturing [56]. Nevertheless few studies focused on manufacture of forest machines. The findings of this study are in line with other findings which report that highest environmental impacts are caused by the use of the machine, mainly due to the consumption of fossil fuels, lubricants and hydraulic oils [29,57]. 
Fossil energy inputs were $15.8 \mathrm{MJ} / \mathrm{m}^{3}$ which are comparable to other studies. For the fully mechanized system "harvester-forwarder", Athanassiadis [58] reported inputs of $82 \mathrm{MJ} / \mathrm{m}^{3}$. Other studies reported values of $52.7 \mathrm{MJ} / \mathrm{m}^{3}$ for a forwarder [29], $59.72 \mathrm{MJ} / \mathrm{m}^{3}$ for a forestry fitted tractor or 17.5 to $31.9 \mathrm{MJ} / \mathrm{m}^{3}$ for chainsaw work [17]. The estimates of this study are smaller as machine diesel consumption is lower than forwarder diesel consumption (e.g., $0.57 \mathrm{~L} / \mathrm{m}^{3}$ [59]) and diesel consumption during machine use is the most impacting regarding fossil energy input.

The LCA showed that potential environmental impacts were quite low for all studied impact categories. Although GWP is one of the most discussed and analyzed impact category, the comparison between studies is often difficult [20]. GWP of MFC for the winching operation to skid trail was $0.321 \mathrm{~kg} \mathrm{CO}$-eq. $/ \mathrm{m}^{3}$. As a comparison, in a review, Klein et al. [20], estimated a mean GWP for the whole timber harvesting from site preparation to forest road at $14.3 \mathrm{~kg} \mathrm{CO}_{2}$-eq. $/ \mathrm{m}^{3}$. For Bavaria (south east Germany) more detailed results showed that biomass felling emitted $3.0 \mathrm{~kg} \mathrm{CO}$-eq. $/ \mathrm{m}^{3}$ and biomass forwarding $2.0 \mathrm{~kg} \mathrm{CO}$-eq. $/ \mathrm{m}^{3}$ [60]. The differences are likely due to the lighter machine which consumed less diesel and lubricants than a forwarder. Another study evaluated GHG emissions from fuel consumption in forest operations. For forest with a "close-to-nature" management, mean emissions were estimated at 0.62 and $6.64 \mathrm{~kg} \mathrm{CO}$-eq. $/ \mathrm{m}^{3}$ for semi-mechanized and fully-mechanized systems [61], these estimates being in line with the results of this research.

Further research should include the whole timber supply chain, including the chainsaw, harvester and forwarder. Carbon storage in trees should also be included as more productive forest area is available when skid trail distances are wider.

\section{Conclusions}

Productivity of winching was affected by volume, number of trees and distance whereas tree species and slope were found to be non-significant. The analysis showed that the use of MFC was a suitable option for winching in terms of time consumption. Nevertheless, when considering the whole system (i.e., harvester processing and forwarder included), overall costs increase. Within the given circumstances (distances between skid trails, volume per tree, etc.) the system costs might be acceptable in a German context, especially for high profit timber assortments. The environmental analysis indicated reduced environmental impacts and energy inputs with low fuel and lubricant consumption on different impact categories.

Winching the tree to the skid trail with an MFC may lead to increased productivity of harvester and forwarder due to higher timber concentrations next to the skid road as the distance between them was enlarged. As a result, lower environmental impacts could be expected since the environmental impacts of harvester and forwarder are high compared to those of the MFC. Moreover, wide skid trail intervals offer extra forest area which could be used for biomass production, and thus, act as a carbon sink.

Further field work and research on MFC, especially considering the whole wood supply chain, may highlight how to improve the sustainability of such harvesting systems. To this end, comparing timber harvesting systems with skid trail distances of 20 and $40 \mathrm{~m}$ should include carbon storage in biomass and revenue from timber. Only then a thorough comparison of costs and environmental impacts between forest operations in stands with larger distance between skid trails (and lateral winching) and a fully mechanized system could be achieved.

Author Contributions: F.B., J.S., and C.S. conceived, designed and performed the experiments; F.B., J.S., and M.F. analyzed the data; F.B. and J.S. wrote the paper with contributions from M.F.

Funding: This study was undertaken in the framework of the project "SOLVE" (Timber harvesting and transportation systems adapted to altered forest structures due to climate change), which is funded by the Federal Ministry of Food and Agriculture (BMEL) and the Federal Ministry for the Environment, Nature Conservation, Building and Nuclear Safety (BMUB) in the frame of the "Förderrichtlinie Waldklimafond" (Förderkennzeichen 28W-B-3-048-01). J.S. is supported by the European Social Fund and by the Ministry of Science, Research and Arts Baden-Württemberg. The article processing charge was funded by the German Research Foundation (DFG) and the University of Freiburg through the funding program Open Access Publishing. 
Acknowledgments: We acknowledge ForstBW (in particular the Maschinenbetrieb Schrofel and Rainer Mohrlok); Peter Forstbetrieb und Transporte; as well as Fernando Rossi and Uwe Uhlich for supporting the data collection.

Conflicts of Interest: "The authors declare no conflict of interest" and "The funders had no role in the design of the study; in the collection, analyses, or interpretation of data; in the writing of the manuscript, and in the decision to publish the results".

\section{References}

1. Cambi, M.; Certini, G.; Neri, F.; Marchi, E. The impact of heavy traffic on forest soils: A review. For. Ecol. Manag. 2015, 338, 124-138. [CrossRef]

2. Enache, A.; Kühmaier, M.; Visser, R.; Stampfer, K. Forestry operations in the European mountains: A study of current practices and efficiency gaps. Scand. J. For. Res. 2016, 31, 412-427. [CrossRef]

3. Goutal, N.; Renault, P.; Cousin, I.; Bonnaud, P.; Gelhaye, D.; Nourisson, G.; Ranger, J. Impact of forest soil compaction on soil atmosphere composition. In Proceedings of the 19th World Congress of Soil Science, Soil Solutions for a Changing World, Brisbane, Australia, 1-6 August 2010; pp. 63-66.

4. Labelle, E.R.; Jaeger, D. Soil Compaction Caused by Cut-to-Length Forest Operations and Possible Short-Term Natural Rehabilitation of Soil Density. Soil Sci. Soc. Am. J. 2011, 75, 2314. [CrossRef]

5. FVA-BW. Richtlinie zur Feinerschliessung; Forstliche Versuchs- und Forschungsanstalt Baden-Württemberg: Freiburg, Germany, 2003.

6. FSC. Deutscher FSC-Standard. Version 3-0; FSC Deutschland: Freiburg, Germany, 2018.

7. Wippel, B.; Kastenholz, E.; Bacher-Winterhalter, M.; Storz, S.; Ebertsch, J. Praxisnahe Anhaltswerte für die mechanisierte Holzernte: Abschlussbericht. Available online: http:/ / www.cluster-forstholz-bw.de/ fileadmin/cluster/cluster_pdf/2015-10-20\%20Bericht\%20Praxisnahe\%20Anhaltswerte.pdf (accessed on 23 February 2017).

8. Tschannen, W. Der 1-Maschinen-Forstunternehmer. Wald und Holz 2013, 8, 51-53.

9. Forst, B.W. Forstlicher Maschinenbetrieb St. Peter. Vorkenzentration der Vollbäume mit Vorrückeraupe an der Seiltrasse: Holzbringung mit Gebirgsharvester; Einsatz des Endmastbaggers. In Tagungsführer zur 17. KWF-Tagung 2016 Roding/Bayern; Kuratorium für Waldarbeit und Forsttechnik e.V., Allgemeine Forst Zeitschfrift: Groß-Umstadt, Germany, 2016; pp. 102-107.

10. Hartkopf, A. Ein Helfer für viele Gelegenheiten: KRUMA 3.0. Forst E Technik 2016, 28, 68-71.

11. Hartkopf, A. Welche Forstraupe für welche Arbeit? Forst \& Technik 2016, 8, 22-25.

12. Waas, S.; Wolf, M.; Schuster, S. KWF-Tagung überzeugt mit innovativer Technik: Weltgrößßte ForstdemoMesse bioetet Einblicke in die Praxis. LWF Aktuell 2016, 4, 52-55.

13. Aggeler, AG. Forstraupe A2100. Available online: http://www.unusuallocomotion.com/medias/files/ forstraupe-a2100.pdf (accessed on 21 September 2018).

14. Christian Achter Forstmaschinen. Rückeraupe KRUMA 3.0: für den Profi im Forst. Available online: https:/ / www.rueckeraupe.de/datenblatt/ (accessed on 5 March 2018).

15. F. Müller Fahrzeugbau GmbH \& Co KG. Rückeraupe MRR. Available online: http://www.muellerforsttechnik.de/upload/6__Rueckeraupe_MRR1104_276.pdf (accessed on 5 March 2018).

16. Wicki Forst, AG. Wicki Forst Raupe 50.6A. Available online: http://www.wickiforst.ch/_v1/pdf/Forst $\%$ 20Raupe.pdf (accessed on 5 March 2018).

17. Pandur, Z.; Šušnjar, M.; Zorić, M.; Nevečerel, H.; Horvat, D. Energy Return on Investment (EROI) of Different Wood Products. In Precious Forests: Precious Earth; Zlatić, M., Ed.; InTech: London, UK, 2015.

18. Deleuze, C.; Morneau, F.; Renaud, J.P.; Vivien, Y.; Rivoire, M.; Santenoise, P.; Longuetaud, F.; Mothe, F.; Hervé, J.C.; Vallet, P. Estimer le volume total d'un arbre, quelles que soient l'essence, la taille, la sylviculture, la station. RDV Tech. ONF 2014, 44, 22-32.

19. KWF. Funktiogrammmatrix: Microsoft Powerpoint Datei “Funktiogrammvorlagen” zum Download. Available online: https://www.kwf-online.de/index.php/forschungsprojekte/replan/306-funktiogrammeerstellen (accessed on 21 September 2018).

20. Klein, D.; Wolf, C.; Schulz, C.; Weber-Blaschke, G. 20 years of life cycle assessment (LCA) in the forestry sector: State of the art and a methodical proposal for the LCA of forest production. Int. J. Life Cycle Assess. 2015, 20, 556-575. [CrossRef] 
21. Berg, S. Terrain Classification System for Forestry Work; Forestry Research Institute of Sweden: Uppsala, Sweden, 1992.

22. Ackerman, P.; Belbo, H.; Eliasson, L.; de Jong, A.; Lazdins, A.; Lyons, J. The COST model for calculation of forest operations costs. Int. J. For. Eng. 2014, 25, 75-81. [CrossRef]

23. ForstBW. (Daten Raupe, Freiburg, Germany). Personal communication, 2018.

24. Forbrig, A.; Steinfath, M. Tagungsführer zur 17. KWF-Tagung 2016 Roding/Bayern; Kuratorium für Waldarbeit und Forsttechnik e.V. (KWF e.V.); AFZ-DerWald: Groß-Umstadt, Germany; Stuttgart, Germany, 2016.

25. KWF. Fäll- und Rückeraupe Pfanzelt Moritz Fr50 mit Eintrommelwinde; Prüfbericht KWF-Püf Nr.: 7718: Groß-Umstadt, Germany, 2018.

26. HeProMo. Eidgenössische Forschungsanstalt WSL: Birmensdorf, Switzerland, 2016. Available online: https:// www.wsl.ch/de/services-und-produkte/software-websites-und-apps/hepromo.html\#tabelement1-tab1 (accessed on 21 September 2018).

27. Umberto; Institut für Umweltinformatik: Hamburg, Germany, 2011.

28. ISO 14040. Environmental Management_Life Cycle Assessment_Principles and framwork; British Standards Institution: London, UK, 2006.

29. Klvač, R.; Ward, S.; Owende, P.M.O.; Lyons, J. Energy Audit of Wood Harvesting Systems. Scand. J. For. Res. 2003, 18, 176-183. [CrossRef]

30. Ecoinvent. Swiss Center for Life Cycle Inventories: St. Gallen, Switzerland, 2010. Available online: http: / / www.ecoinvent.org/ (accessed on 1 October 2014).

31. Athanassiadis, D.; Lidestav, G.; Nordfjell, T. Energy use and emissions due to the manufacture of a forwarder. Resour. Conserv. Recycl. 2002, 34, 149-160. [CrossRef]

32. Knechtle, N. Materialprofile von Holzerntesystemen-Analyse ausgewählter Beispiele als Grundlage für ein forsttechnisches Ökoinventar; Diplomarbeit, ETH Zürich: Zürich, Switzerland, 1997.

33. Ekwaru, J.P.; Veugelers, P.J. The Overlooked Importance of Constants Added in Log Transformation of Independent Variables with Zero Values: A Proposed Approach for Determining an Optimal Constant. Stat. Biopharm. Res. 2017, 10, 26-29. [CrossRef]

34. Duan, N. Smearing Estimate: A Nonparametric Retransformation Method. J. Am. Stat. Assoc. 1983, 78, 605-610. [CrossRef]

35. Végiard, S.; Ung, C.-H. Statistical inference problems related to the logarithmic transformation in regression; another method for interval estimation. Can. J. For. Res. 1993, 23, 871-872. [CrossRef]

36. Pinheiro, J.C.; Bates, D.M. Mixed-Effects Models in S and S-PLUS; Springer: New York, NY, USA, 2001.

37. Spinelli, R.; Visser, R. Analyzing and Estimating Delays in Harvester Operations. Int. J. For. Eng. 2008, 19, 36-41. [CrossRef]

38. Hiesl, P.; Waring, T.M.; Benjamin, J.G. The effect of hardwood component on grapple skidder and stroke delimber idle time and productivity_An agent based model. Comput. Electron. Agric. 2015, 118, 270-280. [CrossRef]

39. Borz, S.A.; Ignea, G.; Popa, B.; Spârchez, G.; Iordache, E. Estimating Time Consumption and Productivity of Roundwood Skidding in Group Shelterwood System-A Case Study in a Broadleaved Mixed Stand Located in Reduced Accessibility Conditions. Croat. J. For. Eng. 2015, 36, 137-146.

40. Ghaffariyan, M.R. Review of European biomass harvesting technologies. Silva Balc. 2010, 11, 5-20.

41. Heinimann, H.R. Forest operations engineering and management-The ways behind and ahead of a scientific discipline. Croat. J. For. Eng. 2007, 28, 107-121.

42. Labelle, E.R.; Soucy, M.; Cyr, A.; Pelletier, G. Effect of Tree Form on the Productivity of a Cut-to-Length Harvester in a Hardwood Dominated Stand. Croat. J. For. Eng. 2016, 37, 175-183.

43. Dietz, P. Dichte und Rindengehalt von Industrieholz. Holz als Roh- und Werkstoff 1975, 33, 135-141. [CrossRef]

44. Borz, S.A.; Ignea, G.; Popa, B. Modelling and comparing timber winching performance in windthrow and uniform selective cuttings for two Romanian skidders. J. For. Res. 2014, 19, 473-482. [CrossRef]

45. Pandur, Z.; Horvat, D.; Šušnjar, M.; Zorić, M.; Hat, Z. Forces Required for Pulling Out a Winch Steel Cable and Physical Load of Chocker-Man. In Proceedings of the 45th International Symposium on Forestry Mechanisation: "Forest engineering: Concern, Knowledge and Accountability in Today's Environment", Dubrovnik, Croatia, 8-12 October 2012.

46. Wirth, J.; Wolff, D. Vergleich von Pferde- und Seilschleppereinsatz beim Vorliefern von Vollbäumen. AFZ DerWald 2008, 63, 968-971. 
47. Zečić, Ž.; Krpan, A.P.B.; Vukušić, S. Productivity of C Holder 870 F tractor with double drum winch Igland 4002 in thinning beech stands. Croat. J. For. Eng. 2005, 26, 49-57.

48. Spinelli, R.; Magagnotti, N.; Laina Relaño, R. An alternative skidding technology to the current use of crawler tractors in Alpine logging operations. J. Clean. Prod. 2012, 31, 73-79. [CrossRef]

49. Vusić, D.; Šušnjar, M.; Marchi, E.; Spina, R.; Zečić, Ž.; Picchio, R. Skidding operations in thinning and shelterwood cut of mixed stands - Work productivity, energy inputs and emissions. Ecol. Eng. 2013, 61, 216-223. [CrossRef]

50. Proto, A.R.; Macrì, G.; Visser, R.; Russo, D.; Zimbalatti, G. Comparison of Timber Extraction Productivity between Winch and Grapple Skidding: A Case Study in Southern Italian Forests. Forests 2018, 9, 61. [CrossRef]

51. Magagnotti, N.; Spinelli, R. Integrating Animal and Mechanical operations in protected Areas. Croat. J. For. Eng. 2011, 32, 489-499.

52. Mousavi, R. Time consumption, productivity, and cost analysis of skidding in the Hyrcanian forest in Iran. J. For. Res. 2012, 23, 691-697. [CrossRef]

53. Ghaffariyan, M.R.; Brown, M. Selecting the efficient harvesting method using multiple-criteria analysis: A case study in south-west Western Australia. J. For. Sci. 2013, 59, 479-486. [CrossRef]

54. Mederski, P.S.; Venanzi, R.; Bembenek, M.; Karaszewski, Z.; Rosińska, M.; Pilarek, Z.; Luchenti, I.; Surus, M. Designing Thinning Operations in 2nd Age Class Pine Stands-Economic and Environmental Implications. Forests 2018, 9, 335. [CrossRef]

55. Mederski, P.S. A comparison of harvesting productivity and costs in thinning operations with and without midfield. For. Ecol. Manag. 2006, 224, 286-296. [CrossRef]

56. Heinimann, H.R. Life Cycle Assessment (LCA) in Forestry: State and Perspective. Croat. J. For. Eng. 2012, 33, 357-372.

57. Engel, A.-M.; Wegener, J.; Lange, M. Greenhouse gas emissions of two mechanised wood harvesting methods in comparison with the use of draft horses for logging. Eur. J. For. Res. 2012, 131, 1139-1149. [CrossRef]

58. Athanassiadis, D. Energy consumption and exhaust emissions in mechanized timber harvesting operations in Sweden. Sci. Total Environ. 2000, 255, 135-143. [CrossRef]

59. Lijewski, P.; Merkisz, J.; Fuć, P.; Ziółkowski, A.; Rymaniak, Ł.; Kusiak, W. Fuel consumption and exhaust emissions in the process of mechanized timber extraction and transport. Eur. J. For. Res. 2017, 136, 153-160. [CrossRef]

60. Klein, D.; Wolf, C.; Schulz, C.; Weber-Blaschke, G. Environmental impacts of various biomass supply chains for the provision of raw wood in Bavaria, Germany, with focus on climate change. Sci. Total Environ. 2016, 539, 45-60. [CrossRef] [PubMed]

61. Cosola, G.; Grigolato, S.; Ackerman, P.; Monterotti, S.; Cavalli, R. Carbon Footprint of Forest Operations under Different Management Regimes. Croat. J. For. Eng. 2016, 37, 201-217. 